\title{
ECOLOGICAL COMPETENCE OF A FUTURE TEACHER AS A COMPONENT OF EDUCATIONAL PROGRAMS: PROBLEMS AND PROSPECTS
}

\begin{abstract}
Maryna Khrolenko ${ }^{1}$
${ }^{1}$ Candidate of Pedagogical Sciences, Associate Professor, Associate Professor at the Department of Theory and methodics of teaching natural sciences Oleksandr Dovzhenko Hlukhiv National Pedagogical University, Hlukhiv, Ukraine, e-mail: marina.khrolenko@gmail/com, ORCID: https://orcid.org/0000-0002-2118-1977
\end{abstract}

Abstract. The article is dedicated to the problem of the ecological competence formation of the future biology teachers during professional training. Ecological competence formation of the future biology teachers is considered as a competence approach in a synergistic combination with systematic, personally oriented, activities, axiological, technological, contextual, reflexive and coevolutionary-noosphere methodological approaches. On the analysis basic of the educational programs of higher education establishments of Ukraine we found out the current state of the students' ecological competence formation on the first level (Bachelor's degree) of the subject specialty 014.05 Secondary Education (Biology and Human Health).

Among a great number of general competencies, we will highlight the ones that the future ecologically competent biology teacher should master. Professional competencies of educational and professional programs of higher education establishments of Ukraine that train future biology teachers have been analyzed through the prism of the structural components of ecological competence such as: cognitive, axiological, activity-operational and component of readiness for formation of eco-competence of the pupils. It has been found out that not all the educational and professional programs, on which basis the future biology teachers training is performed, consider ecological competence as professional. Some EPPs present only certain structural components of eco-competence. In particular, the axiological component of ecological competence, aimed at the formation and development of needs, interests, motives, values of interaction of the students with the environment, is not reflected separately in the professional abilities of educational and professional programs of higher education institutions of Ukraine.

In this article we clarified the abilities that provide for the formation of the structural components of ecological competence, educational and professional programs of Bachelor's degree. We paid attention to the formulation of ecological competency as professional that joins all its components.

Keywords: competence, ecological competence, program learning outcomes, educational program, future biology teachers.

JEL Classification: I24, I29

Formulas: 0; fig.: 0; tabl.: 0; bibl.: 29

Introduction. Modern labor market demands from a graduate of a higher education establishment not only deep theoretical knowledge, but also the ability to use it on his own in non-standard, constantly changing life situations, moving from the knowledge society to the society of vitally competent citizens [1]. The proper level of the pupils' ecological competence at the secondary education establishments may be provided by pedagogical staff, especially biology teachers, with highly formed such a personal characteristic.

Bachelor's degree program in subject specialties 014.05 Secondary education (Biology) and 014.05 Secondary education (Biology and Human Health) is implemented according to educational and professional programs (EPP) in higher education establishments of Ukraine. Claiming the principle of the autonomy and 
self-government of a higher education establishment. The Law of Ukraine «About higher education» [2] gives it the opportunity to create and realize educational programs by itself at the frames of licensed specialties referring on higher education standard of proper specialty (Clause 32). Considering the fact that the central executive institution in the field of education and science does not elaborate the higher education standard of the mentioned subject specialties, higher education establishments work out and ratify internal standards of specialties and educational degrees by themselves according to the appointed order, on which basis educational programs are being created. However, not all the educational and professional programs consider ecological competence as professional. Some EPPs present only certain structural components of eco-competence.

Literature Review. Analyzing the state of ecological competence formation of the future biology teachers, we base on the scientists' research results regarding competence approach of: future teachers training for the pupils' competencies formation (N. Baiurko [3]); training system of students for professional activity on the competence approach basis (N. Hrytsai [4], O. Molchaniuk [5], O. Plakhotnik [6], O. Ptashenchuk [7], O. Chubrei [8], I. Shmyhol [9]); ecological competence formation of students (Yu. Boichuk [10], O. Hurenkova [11], L. Lukianova [12], N. Oliinyk [13], L. Tytarenko [14], A. Khrypunova [15], Yu. Shapran [16] etc.). Scientific research regarding the role of the educational components during ecological competence formation of students is important at the frames of our research (Ya. Absaliamova [12], Ya. Lohvinova [17], O. Mateiuk [18], I. Siaska [19] etc.).

The analysis of available scientific research proves the highest priority of the competence approach. Ecological competence takes the most important place in the educational process among a great number of competencies claimed by a teacher's professional standard. However, most of the EPPs claim individual components of analyzed competence only in their content what is reflected in the context of educational components and program education results.

Aims. The aim of the article is to determine the state of ecological competence formation of future biology teachers through the analysis, comparing the educational and professional programs, syllabuses, programs of educational disciplines of a great number of higher education establishments of Ukraine; to highlight the abilities that provide for the formation of the structural components of ecological competence, educational and professional programs of Bachelor's degree; to offer the formulation of ecological competency as professional that joins all its components.

Methods. We explore ecological competence of future teachers as a competence approach in a synergistic combination with systematic, personally oriented, activities, axiological, technological, contextual, reflexive and co-evolutionary-noosphere methodological approaches. Realization of aims and tasks foresaw using the methods of scientific knowledge: analysis, synthesis, comparing, generalization, modeling, etc.

Results. In order to find out the state of the ecological competence formation of the future biology teachers we analyzed educational and professional programs, 
syllabuses, programs of educational disciplines of a great number of higher education establishments of Ukraine, which prepare bachelors of the specialties 014 Secondary education (Biology) and 014 Secondary education (Biology and human health), grant the students with the educational and professional degree «Bachelor of Education. Biology Teacher», or «Bachelor of Secondary Education. Teacher of Biology and Basics of Health», or «Bachelor of Education. Biology Teacher. Teacher of Natural Sciences» etc.

All the programs created by higher education establishments of Ukraine are based on the competence approach and recommendations, presented in a program document «Reference Points for the Design and Delivery of Degree Programmes of Educations», which was elaborated as a component of the TUNING project along with the support of the European Commission.

We proceeded content analysis of educational and professional programs regarding the existence of ecological competence and program learning outcomes at higher education establishments of Ukraine such as: Berdiansk State Pedagogical University, Vinnytsia State Pedagogical University named after Mykhailo Kotsiubynskyi, Hlukhiv National Pedagogical University named after Oleksandr Dovzhenko, Drohobych State Pedagogical University named after Ivan Franko, Zaporizhzhia National University, Kremenets Regional Academy of Humanities and Pedagogy named after Taras Shevchenko, Kryvyi Rig State Pedagogical University, Mykolaiv National University named after V. O. Sukhomlynskyi, Melitopol State Pedagogical University named after Bohdan Khmelnytskyi, National Pedagogical University named after M. P. Drahomanov, National University "Chernihivskyi kollehium" named after T. H. Shevchenko, Poltava National Pedagogical University named after V. H. Korolenko, Rivne State Humanitarian University, Eastern European National University named after Lesia Ukrainka, Ternopil National Pedagogical University named after Volodymyr Hnatiuk, Uman State Pedagogical University named after Pavlo Tychyna, Kharkiv National Pedagogical University named after H. S. Skovoroda, Kherson State University, Khmelnytskyi National University, Chernivtsi National University named after Yu. Fedkovych.

Analysis of educational and professional programs of mentioned educational establishments proved the fact that integral competence is interpreted almost in the same way in most of programs with minor content variations. Its sense is generalized in the formulation: the ability to solve difficult specialized practical tasks of the secondary education branch that foresees using conceptual methods of educational sciences, psychology, theory and methods of biology and basics of health teaching are characterized by complexity and uncertainty of the conditions of educational process organization in secondary education establishments. Integral competence at National qualifications framework of Ukraine is a key concept used regarding the generalized description of qualification level that shown main competence characteristics of the level in regard to education / professional activity. Mentioned competence clarifies the major ability of bachelors, future biology teachers to perform or solve tasks of certain difficulty level during professional activity or studying. Integral competence is specified by the major of general and professional 
competencies.

General EPPs competences of higher educational establishments varies from 10 - similar to the standard project of the specialty $[20,21]$ to 15 - more detailazed such as: the ability to think abstactly, analyse and synthesize; the ability to use knowledge practically; the ability to plan and manage the time, speak state language and write using it; the ability to speak any foreign language; skills of using information and communication technologies; the ability to research on a proper level; the ability to master up-to-date knowledge and proceed leaning autonomically; the ability to search, process and analyse the information from different sources; the ability to generate new ideas (creativity); the ability to work as a part of a team using proper communication skills; skills to do safe activities; the ability to act on the ethical considerations basis; the ability to save and increase moral, cultural, scientific values and society's achievements based on realizing the history and development patterns of the subject branch, its place in general system of knowledge about nature and society, in society's development, technologies, various types and forms of physical activity for active recreation and a healthy lifestyle; the ability to realize the own rights and duties as a member of society, to be aware of the values of civil (free democratic) society and the need for its sustainable development, the rule of law, human and civil rights and freedoms in Ukraine [22]. From all the mentioned competencies we would highlight the ones that future ecologically competent biology teacher should master: the ability to save and increase moral, cultural, scientific values and society's achievements based on realizing the history and development patterns of the subject branch, its place in a general system of knowledge about nature and society, in society's development, technologies, various types and forms of physical activity for active recreation and a healthy lifestyle; the ability to study and master up-to-date knowledge; the ability to use knowledge practically; the ability to act on the basis of the ethical considerations; the ability to think systematically, critically and creatively.

Professional (subject, special) competencies are specified in regard to the subject branch of the specialty. They are the vital condition for implementing successful professional activity according to the specialty. Professional competencies are directed to the knowledge of the subject branch (describes the acts: knows, names, clarifies, describes, searches, reproduces, organizes, shows, sets a connection), understanding (classifies, finds out, highlights, explains, expresses, interprets, concludes, recognizes), using of knowledge (uses, chooses, demonstrates, elaborates, finds out, searches, illustrates, organizes, foresees, prepares, plans, describes), acts estimation (estimates, argues, chooses, combines, compares, measures, recommends).

We analyzed the professional competencies of educational and professional programs of the above-mentioned higher education institutions that train future biology teachers through the prism of the structural components of environmental competence, such as: cognitive, axiological, activity-operational and the component of readiness for the formation of eco-competence of students. Thus, the following abilities of the future teacher's EPPs are aimed at the formation of the cognitive component of ecological competence: the ability to understand and be able to explain 
the structure, functions, vital activity, reproduction, classification, origin, distribution, use of living organisms and systems of all levels of organization [23]; ability to reveal the essence of biological phenomena, processes and technologies, to solve biological problems [20], ability to reveal the general structure of biological science based on the relationships of the main studies of biology to characterize living systems of different levels of organization; ability to understand and explain the strategy of sustainable development humanity [24]; ability to describe a wide range of natural objects and processes (both natural and artificially created), starting from the integrity of the biosphere (including its evolution from the moment of creation to the present day) and ending with the molecular level of living organization [25]; ability to reveal the general structure of biological science on the basis of the relationships of the main studies of biology to characterize living systems of different levels of organization [21]; ability to characterize the achievements of biological and chemical sciences, to identify their role in society to ensure sustainability of development of biological systems, to implement the strategy of sustainable development of the biosphere [26]; ability to analyze the results of interaction of biological systems of different levels of organization, their role in the biosphere and the possibility of use in different sectors of the economy, biotechnology and environmental protection [22].

The axiological component of ecological competence, aimed at the formation and development of needs, interests, motives, values of interaction of students with the environment, is not reflected separately in the professional abilities of educational and professional programs of domestic higher education institutions.

Activity-operational component of the studied phenomenon can be traced in a number of subject (special) competencies: the ability to understand and implement the strategy of sustainable development of mankind in the process of professional activity [23]; ability to use biological concepts, laws, concepts, teachings and theories of biology to explain and develop students' understanding of the integrity and interdependence of living systems and organisms [20]; the ability to demonstrate the role of biology knowledge in the everyday life for the purposes of biodiversity conservation and sustainable development [27]; the ability to organize and promote work to preserve the environment among participants of the educational process [25]; ability to conserve biodiversity, protect the environment and rationally use nature [22].

The most significant abilities in the EPPs of bachelors of the subject specialty 014.05 Secondary education (Biology and Human Health), which provide readiness for the formation of environmental competence of students, are: the ability to develop students' cognitive activity, ecological thinking, to form ecological culture and ecologically appropriate behavior; to develop students' sense of belonging and responsibility for the preservation of nature, its perception as the ideal of harmony and perfection of life [23]; ability to form ecological-educational and nature protection consciousness of the people involved in training, to promote the formation of ecological culture in general and out-of-school educational institutions [28]; ability to apply the acquired knowledge of biology, modern methods, tools and educational 
technologies for the formation of students' general and subject competencies [29].

To sum it up, ecological competence is presented by individual structural components such as a cognitive, behavioral, component of readiness to form pupils' ecological competence in educational and professional programs of future biology teachers' training in higher education establishments of Ukraine. The axiological structural-functional component is not presented at all. In our opinion, any of analyzed programs does not contain full professional ecological competence aimed at ensuring the ability to operate with a system of environmental knowledge, to have a systemic integrity of acquired environmental values, methods of studying and researching phenomena, objects and processes of the environment, the implementation of the functions of environmental education in professional activities.

The program learning outcomes of the analyzed educational and professional programs meet the requirements of the National qualifications framework in the condition of the absence of standards of higher education on the relevant specialty. In this way, the program learning outcomes reflect the following descriptors of the National qualifications framework: knowledge, skills, communication, autonomy and responsibility. However, not all the analyzed educational programs the formation of the outlined competence are traced in the program learning outcomes. Among the program learning outcomes that provide with formed individual components of students' ecological competence we highlighted the following: understands and characterizes the strategy of sustainable development and reveals the essence of the relationships between the environment and human; selects interdisciplinary links of biology courses in the basic secondary school in order to form students' natural science competence in accordance with the requirements of the State Standard of General Secondary Education in the field of education «Nature Science» [23]; knows the role of living organisms and biological systems of different levels in society, their using, protection, reproduction [24]; able to apply knowledge of modern theoretical foundations of biology to explain the structure and functional characteristics of organisms at different levels of organization of alive beings, their interactions, relationships, origin, classification, value, using and distribution; understands and characterizes the strategy of sustainable development and reveals the essence of the relationships between the environment and human; knows the leading principles of ecosystem functioning, assesses the impact of environmental factors on human health [20]; knowledge and understanding of the fundamentals of general ecology, principles of co-evolution of society and nature, mechanisms of functioning of natural systems, principles of optimal environmental management and environmental protection [27]; demonstrates knowledge of the laws of interaction of living organisms of cellular and non-cellular life forms with each other, the influence of various factors on living organisms and their role in the processes of transformation of substances and energy in the biosphere; demonstrates knowledge and understanding of the basics of general ecology, principles of optimal nature management and nature protection [25]; applies knowledge of modern theoretical foundations of biology, chemistry, ecology and valeology to explain the structure and functional characteristics of organisms at different levels of living organization, their 
interaction, relationships, origin, classification, meaning, using and distribution [22]; demonstrates knowledge and understanding of the basics of ecology, principles of optimal nature management and nature protection, contributes to the formation of ecological consciousness [28].

Discussion. The results obtained during the analysis of educational programs, syllabuses of higher education establishments of Ukraine regarding the role of ecological competence in the educational process of future biology teachers, in comparison with the previously mentioned works of other researchers, relate to the clarification of the structural and functional components of eco-competence (cognitive, axiological, operational, reflective) in educational programs.

Conclusion. Summarizing, due to content-analysis of educational programs, syllabuses of state higher education establishments that train future biology teachers and survey of scientific and pedagogical staff let us conclude:

1. educational programs of higher education establishments of Ukraine foresee the formation of a great number of abilities which mainly correspond to cognitive and activity-operational components of environmental competence;

2. the formulation of full professional ability "ecological competence" such as "the ability to operate a system of ecological knowledge, to possess systemic integrity of the acquired ecological values, motives, ways of activity on studying and research of the phenomena, objects and processes of environment, realization of functions of ecological education in professional activity, readiness for the formation of ecological competence of pupils is absent;

3. some educational programs only (12\%) represent the formation of described competencies in program learning outcomes.

Considering all mentioned above, we may not proclaim the existence of the integrated system of the ecological competence formation of the future biology teachers during professional training at analyzed higher education establishments of Ukraine.

The subject of further research is to study the content of educational programs of domestic higher education institutions with normative and selective educational components of the training cycle, which are aimed at forming the environmental competence of future biology teachers.

Author contributions. The authors contributed equally.

Disclosure statement. The authors do not have any conflict of interest.

\section{References:}

1. Natsionalna stratehiia rozvytku osvity v Ukraini na period do 2021 roku [National strategy for the development of education in Ukraine until 2021]. Retrieved from: http://zakon4.rada.gov.ua/laws/show/344/2013 [in Ukrainian].

2. Zakon Ukrainy «Pro vyshchu osvitu» [Law of Ukraine "On Higher Education"]. Retrieved from: https://zakon.rada.gov.ua/laws/show/1556-18\#Text [in Ukrainian].

3. Baiurko, N. V. (2017). Pidhotovka maibutnikh uchyteliv biolohii do rozvytku ekolohichnoi kompetentnosti uchniv osnovnoi shkoly [Preparation of future biology teachers for the development of environmental competence of primary school students], Vinnytsia: TOV "Nilan LTD” [in Ukrainian].

4. Hrytsai, N. B. (2016). Systema metodychnoi pidhotovky maibutnikh uchyteliv biolohii $\mathrm{v}$ pedahohichnykh universytetakh [The system of methodical training of future biology teachers in pedagogical universities]. Doctor's thesis. Kyiv [in Ukrainian].

5. Molchaniuk, O. V.(2018). Vykhovannia $\mathrm{v}$ maibutnikh uchyteliv biolohii tsinnisnoho stavlennia do pryrody : metodolohiia, teoriia, praktyka : monohrafiia [Education of future teachers of biology of values to nature: methodology, theory, practice: a monograph], Kharkiv : Vydavets O. A. Miroshnichenko [in Ukrainian]. 
6. Plakhotnik, O., Beznosiuk, O. (2013). Kompetentnisnyi pidkhid u VNZ: problemy ta perspektyvy [Competence approach in higher education: problems and prospects.]. Naukovi zapysky [Kirovohradskoho derzhavnoho pedahohichnoho universytetu imeni Volodymyra Vynnychenka]. Ser. : Pedahohichni nauky, 121(2), 200-205 [in Ukrainian].

7. Ptashenchuk, O. O. (2018). Formuvannia doslidnytskoi kompetentnosti maibutnikh uchyteliv biolohii u protsesi profesiinoi pidhotovky [Formation of research competence of future biology teachers in the process of professional training]. Extended abstract of candidate's thesis. Sumy [in Ukrainian].

8. Chubrei, O. S. (2020). Systema pidhotovky maibutnikh uchyteliv heohrafii do profesiinoi diialnosti na zasadakh kompetentnisnoho pidkhodu [The system of training future teachers of geography for professional activity on the basis of the competence approach]. Doctor's thesis. Khmelnytskyi [in Ukrainian].

9. Shmyhol, I. V. (2013). Formuvannia zahalnopredmetnykh kompetentnostei z pryrodnychykh dystsyplin u profesiinii pidhotovtsi maibutnikh uchyteliv biolohii ta khimii [Formation of general subject competencies in natural sciences in the training of future teachers of biology and chemistry]. Extended abstract of candidate's thesis. Cherkasy [in Ukrainian].

10. Boichuk, Yu. D. (Ed.). (2014). Formuvannia ekoloho-valeolohichnoi kompetentnosti maibutnoho vchytelia u protsesi biolohichnoi pidhotovky: teoretyko-metodychni aspekty: metod. rekom. dlia vykl. ped. navch. Zakl [Formation of ecological and valeological competence of the future teacher in the process of biological training: theoretical and methodological aspects: method. rekom. to off. ped. textbook lock]. Kharkiv: KHNPU im. H. S. Skovorody [in Ukrainian].

11. Hurenkova, O. V. (2009). Formuvannia ekolohichnoi kompetentnosti maibutnikh fakhivtsiv vodnoho transport [Formation of ecological competence of future specialists of water transport in the conditions of credit-modular system of training]. Candidate's thesis. Kyiv [in Ukrainian].

12. Absaliamova, Ya., Lukianova, V. (2017). Formuvannia ekolohichnoi kompetentnosti maibutnikh fahivtsiv zasobamy sotsialno-humanitarnykh dystsyplin [Formation of ecological competence of future specialists by means of social and humanitarian disciplines]. Scientific Letters of Academic Sosiety of Michal Baludansky, 2, 6-7 [in Ukrainian].

13. Oliinyk, N. Yu. (2005). Formuvannia profesiinoi ekolohichnoi kompetentnosti studentiv hidrometeorolohichnoho tekhnikumu u protsesi navchannia informatsiinykh tekhnolohii [Formation of ecological competence of students of hydrometeorological technical school in the process of teaching information technologies]. Extended abstract of candidate's thesis. Kharkiv [in Ukrainian].

14. Tytarenko, L. M. (2007). Formuvannia ekolohichnoi kompetentnosti studentiv biolohichnyh spetsialnostei universytetu [Formation of ecological competence of students of biological specialties of the university:]. Extended abstract of candidate's thesis. Kyiv [in Ukrainian].

15. Khrypunova, A. L. (2009). Formuvannia ekolohichnoi kompetentnosti maibutnikh inzheneriv-fakhivtsiv tsyvilnoho zahystu [Formation of ecological competence of future engineers - specialists of civil protection]. Extended abstract of candidate's thesis. Kharkiv [in Ukrainian].

16. Shapran, Yu. P. (2012). Ekolohichna kompetentnist maibutnikh uchyteliv biolohii: yii sutnist ta diahnostyka [Ecological competence of future biology teachers: its essence and diagnostics]. Prohres u nautsi za ostanni roky. Novi rishennia: zb. dopovid. nauk, 3/2, 29-36 [in Ukrainian].

17. Lohvinova, Ya. O. (2014). Formuvannia ekolohichnoi kompetentnosti maibutnoho vykladacha biolohii u protsesi vyvchennia pryrodnychyh dystsyplin [Formation of ecological competence of the future teacher of biology in the process of studying natural sciences]. Extended abstract of candidate's thesis. Kirovohrad [in Ukrainian].

18. Mateiuk, O. P. (2011). Formuvannia profesiinoi ekolohichnoi kompetentnosti studentiv universytetu u konteksti zavdan staloho rozvytku [Formation of professional ecological competence of university students in the context of sustainable development tasks]. Visnyk Natsionalnoi academii Derzhavnoi prykordonnoi sluzhby Ukrainy, 1. Retrieved from: http://nbuv.gov.ua/UJRN/Vnadps [in Ukrainian].

19. Siaska, I. O. (2018). Sutnist ekolohichnoi kompetentnosti ta osoblyvosti yii formuvannia u maibutnikh vchyteliv pryrodnychyh dystsyplin [The essence of ecological competence and features of its formation in the future teacher of natural sciences]. Innovatyka u vyhovanni, 8. Retrieved from: http://nbuv.gov.ua/UJRN/inuv [in Ukrainian].

20. Osvitno-profesiina prohrama «Serednia osvita (Biolohiia ta zdorovia liudyny)» Khersonskoho derzhavnoho universytetu [Educational and professional program «Secondary education (Biology and human health)» of Kherson State University]. Retrieved from: http://www.kspu.edu/About/Faculty/Faculty_of_biolog_geograf_ecol/program2.aspx [in Ukrainian].

21. Osvitno-profesiina prohrama «Serednia osvita (Biolohiia ta zdorovia liudyny)» Natsionalnoho universytetu «Chernihivskyi kolehium» imeni T. H. Shevchenka [Educational and professional program «Secondary education (Biology and human health) of the National University «Chernihiv Collegium» named after Taras Shevchenko]. Retrieved from: :https://drive.google.com/file/d/19QiRplOz9FrWeCZUbPjQEgPcNfSmmcJg/view [in Ukrainian].

22. Osvitno-profesiina prohrama «Serednia osvita (Biolohiia ta zdorovia liudyny)» Kremenetskoi oblasnoi humanitarnopedahohichna akademii imeni Tarasa Shevchenka [Educational and professional program «Secondary education (Biology and human health)» of Kremenets Regional Humanitarian and Pedagogical Academy named after Taras Shevchenko]. Retrieved from: http://www.kogpi.edu.te.ua/images/stories/Henrikh/bio_kaf/BIOZD_OPP_2019.pdf [in Ukrainian]. 
23. Osvitno-profesiina prohrama «Serednia osvita (Biolohiia ta zdorovia liudyny ta pryrodoznavstvo)» Hlukhivskoho natsionalnoho pedahohichnoho universytetu imeni Oleksandra Dovzhenka [Educational-professional program «Secondary education (Biology and human health and natural sciences)» of Hlukhiv National Pedagogical University named after Oleksandr Dovzhenko]. Retrieved https://drive.google.com/file/d/12t59BWussblJsVfc7vJ4KljI7wVcSkFf/view [in Ukrainian].

24. Osvitno-profesiina prohrama «Serednia osvita (Biolohiia ta zdorovia liudyny. Khimiia)» Melitopolskoho derzhavnoho pedahohichnoho universytetu im. B. Khmelnytskoho [Educational and professional program «Secondary education (Biology and human health. Chemistry)» Melitopol State Pedagogical University named after B. Khmelnitsky]. Retrieved from: https://mdpu.org.ua/wp-content/uploads/2021/02/Serednya-osvita.-Biologiya-tazdorov-ya-lyudini.-Himiya.pdf [in Ukrainian].

25. Osvitno-profesiina prohrama «Serednia osvita (Biolohiia ta zdorovia liudyny. Psykholohiia)» Umanskoho derzhavnoho pedahohichnoho universytetu im. P. Tychyny [Educational and professional program «Secondary education (Biology and human health. Psychology)» Uman State Pedagogical University named after P. Tychyna]. Retrieved from: https://udpu.edu.ua/navchannia/osvitni-prohramy/45523 [in Ukrainian].

26. Osvitno-profesiina prohrama «Serednia osvita (Biolohiia ta zdorovia liudyny, khimiia)» Ternopilskoho NPU im. V. Hnatiuka [Educational and professional program «Secondary education (Biology and human health, chemistry)» Ternopil National Pedagogical University named after V. Hnatiuk]. Retrieved from: http://tnpu.edu.ua/about/public inform/akredytatsiia\%20ta\%20litsenzuvannia/osvitni_prohramy/bakalavr/himbio/014.0 5 2020.pdf [in Ukrainian].

27. Osvitno-profesiina prohrama «Serednia osvita (Biolohiia ta zdorovia liudyny)» DU Luhanskyi natsionalnyi universytet im. T. Shevchenka [Educational and professional program «Secondary education (Biology and human health)» of Luhansk National University named after T. Shevchenko]. Retrieved from: http://luguniv.edu.ua/?page id=349 [in Ukrainian].

28. Osvitno-profesiina prohrama «Serednia osvita (Biolohiia ta zdorovia liudyny. Heohrafiia)» Dniprovskoho natsionalnoho universytetu im. O. Honchara [Educational and professional program «Secondary education (Biology and human health. Geography)» of Dnipropetrovsk National University named after O. Honchar]. Retrieved from: http://www.dnu.dp.ua/view/osvitni_programy [in Ukrainian].

29. Osvitno-profesiina prohrama «Serednia osvita (Biolohiia ta zdorovia liudyny)» Kamianets-Podilskoho natsionalnoho universytetu im I. Ohiienka [Educational and professional program «Secondary Education (Biology and Human Health)» of Kamyanets-Podilsky National University named after I. Ogienko]. Retrieved from: http://nature.kpnu.edu.ua/abituriientam/[in Ukrainian]. 